Political Philosophy and the Real World of the Welfare State

Jonathan Wolff

Abstract: What contribution can political philosophers make to policy questions, such as the best configuration of the welfare state? On one view, political philosophers set out abstract theories of justice that can guide policy makers in their attempt to transform existing institutions. Yet it rarely seems the case that such a model is used in practice, and it therefore becomes unclear how political philosophy can contribute to policy debates. Following a suggestion from Margaret MacDonald, I consider the view that political philosophers can contribute by drawing attention to relatively neglected values. I develop this view to add the possibility that political philosophers can try to correct a situation in which a particular value, though important, can come to be too highly emphasized. I illustrate the account by considering the rise of the value of 'responsibility' in the welfare state, and ultimately the damage that has been done to society to disadvantaged groups by the over-insistence on the importance of responsibility.

1. Methodology in Political Philosophy Today

Can abstract reasoning in political philosophy have an influence on public policy? One model of how this can happen is that, on the basis of sustained philosophical reflection and argument, using all the tools on the philosophical workbench, philosophers develop theories of justice. These theories are then taken up by politicians and policy makers and applied to real situations, leading to philosophically informed policy. On this view a model is provided of a perfectly just world - as if the political philosopher is the legislator for an ideal kingdom of the imagination - and the real world is to be changed so as to conform with the theory. Now, it will be conceded that matters of practicality make it unlikely that the theory will be applied in anything approaching pure form. Yet it is not 
unreasonable to think that empirical reality can be brought more in the direction of some theoretical ideal than it has been in the past. For example, it is commonly believed that Lockean ideas influenced the American revolution, egalitarian ideas the development of the welfare state, and Nozickian libertarianism may have influenced the direction taken in Thatcherite social policy; a topic we will return to below. In more recent decades we have seen a flirtation with communitarian ideas, although it is harder to see any connection with policy changes.

According to this way of connecting theory and policy, a philosophical theory of justice is articulated into some sort of model of an ideally just society, which is then used as a type of blueprint or architect's model of a society. However, given that, socially, we are never building an entirely new building, compromise is needed. We have to adjust what we have, and thereby try to make it resemble the blueprint as much as we can, rather attempt to realise the blueprint in full detail.

There is, I think, something correct in this suggestion about how political philosophy can have an influence on actual policy, although we will need to modify the account in significant ways. To come to a more descriptively accurate view it will, first of all, be useful to confront some apparent difficulties with what we can call the 'blueprint' model. And indeed the analogy with architecture immediately suggests some oddities. Does any architect ever propose modifications to a building by drawing up plans for an ideal building, paying no attention to the existing building, and then see how much of the ideal building can be established by modifying the existing one? Perhaps some highly demanding clients have instructed their architects to build in this fashion, but it is easy to see its difficulties, and the tensions - in the architectural case, literally so - that will arise.

The architect, making modifications, should not, then, start by trying to imagine the best building possible, but, perhaps, the best possible building (subject to planning, financial and other constraints such as the client's own ideas) given what already exists. And in parallel it has been suggested by Bernard Williams that our task as political philosophers is not to try to envisage the best society possible: rather it is to try to work out what we can achieve 
starting from what is at hand. ${ }^{1}$ By contrast, starting by trying to imagine the ideally best possible society, and then trying to change society so that it resembles it to the greatest extent, runs the danger of producing something far worse than if we gone about the task in much more pragmatic fashion. ${ }^{2}$ This is simply one version of the 'theory of the second best'.

In recent work Sen has developed such a position in more detail. One possible way of setting out the type of contextual position mentioned by Williams would suggest that we should look for the best we can achieve starting from here. Sen, I believe, would question whether it is necessary or even helpful to look for the 'best' even when the best is constrained by 'starting from here'. ${ }^{3}$ Instead of the best, we should look for what we might call the manifestly and uncontroversially better. Again, the architectural metaphor may help. In improving a building, how much place is there for reflection on the idea of the 'best' building we could create starting from here? Isn't the right thing to do to consider ways in which it can be made better, rather than start with an idea of what would be the very best?

Now this may seem defeatist, but one reason for arguing that considering the best will be unhelpful is that the notion of 'the best' will be highly contested. In the architectural case, the architect, the client, and the town planner may all have quite different ideas. What, then, is 'the best'? How can we know? Turning back to political philosophy, this is, perhaps, the most obvious difficulty with the blueprint model, and a charge Engels, for example, memorably made against the utopian socialists. Each utopian had his own blueprint, his own model of the ideal society, and each, supposes Engels, believed his model reflected the eternal truth about justice. But all the models were different. Which, if any, really captured the nature of justice? ${ }^{4}$ How could you tell? How could you convince others? And as Alasdair MacIntrye has remarked, if you do not have arguments that would convince others, how is it that you came to be convinced yourself? ${ }^{5}$

We have seen, then, two reasons for questioning the blueprint model. First, in politics we are always in the business of making changes, not starting afresh. Trying to change the world so that it maximally conforms with an ideal can lead to serious problems if the ideal is not achievable. Second, all ideals are contested, and there is no standard of argument or proof where one can be 
established over others to the satisfaction of all.

In response it might well be asked whether any beneficial change will be possible unless we accept that some ideals are better than others. If ideals are contested how can we tell that a change is even for the better? If we do not have an idea of what would be best, how can we know what would be better?

But, it seems, there can be agreement that something is better even without agreement on what is best. Consider two famous examples from Amartya Sen himself: famines and missing women. Regarding famines, Sen argued that famines are not principally caused by lack of food, but rather lack of entitlement to food. And in a well-functioning democracy with a free press famines do not happen, as it is not actually difficult to feed a population if there is the will to do it. As allowing the people to starve is not a way of getting reelected, the combination of publicity and democracy will ensure that there is protection against famine, at least in normal circumstances. ${ }^{6}$ Consequently famines are political failures, not highly unfortunate, but ultimately random events.

Regarding missing women, Sen reports that there are far fewer women alive in the world - many millions fewer - than biology alone would predict, suggesting that neglect has led to poorer survival rates for young girls than for their brothers. ${ }^{7}$ Both of these facts about the world are likely to give rise to a widespread belief that current political and social practices in these respects are unjustified and that changes are called for. It is not difficult to think of ways of changing things for the better. But we can do this without having a blueprint of a 'best' society in our heads. ${ }^{8}$

These examples of 'manifest injustice' are striking. However, in the practical politics of a modern liberal democratic society many of our disputes are of a less dramatic nature. Sen draws our attention to phenomena that previously were neglected, but once named and shamed will roundly be condemned. Probably there are still some issues that afflict current liberal democracies and will shock us when we come to reflect on them. For example, the relatively recent criminalization of marital rape shows that countries can let a serious injustice go unrecognized even in broadly enlightened times. However, the disputes of contemporary politics are just that: disputes, with many sides to 
them, and weighty voices on more than one side.

In the face of such disagreement Sen seems to recommend democratic procedures. In practical terms this is reasonable enough, but for those who had the hope that philosophical theory can resolve contentious issues it is a disappointing result. On this account philosophical thinking appears to have a role only where it isn't needed: where there is sufficient consensus on a policy that no arguments are required. But on reflection, was philosophical even needed to identify manifest injustice? Note that Sen's contribution in these cases was largely empirical. It was Sen the social scientist, not Sen the philosopher, who brought our attention to famine and missing women.

The problem, then, can be put like this. Political philosophy has to be focused on a particular concrete situation or problem if it is to make a genuine contribution to practical affairs. In some cases, where the problem or injustice is very clear once described, there appears to be nothing more for political philosophy to do once the problem is identified. It is a matter of bringing to attention something that earlier we had failed to notice and social science may be better for this than philosophy. If, on the other hand, the issue is contested then it appears that political philosophy seems desperately needed, but it is hard to see how it can settle any issues. There is no methodology for recognizing the force of the better argument. This does not mean that ideal theory is empty or useless. But it does raise a question of how political philosophy can influence real politics.

2. Methodology in Political Philosophy in the 1940s and 1950s

I would like to try to make some headway on this issue by going back about sixty years, to another time when political philosophy was especially methodologically self-conscious, but even more dispirited: to the famous preface to Laslett's edited collection Philosophy, Politics and Society. ${ }^{9}$ Laslett remarkably, in the editor's introduction to a collection of then new and recent writing in political philosophy, manages the reader's expectations dramatically downwards by declaring: 'For the moment, anyway, political philosophy is dead'.10 
Laslett considers three factors that have led to this unhappy situation. One is the rise of logical positivism. Another is the growing influence of sociology in which political ideas, and their rise and fall, are to be considered as objects of social analysis rather than possible bearers of truth or even independent significance. But also Laslett suggests that the horrors of the second world war exerted powerful influence: 'Faced with Hiroshima and with Belsen, a man is unlikely to address himself to a neat and original theory of political obligation.'11

While one can sympathise with Laslett's point, early in the second world war, admittedly prior to Hiroshima and Belsen, an insightful paper appeared in which a woman, not a man, did indeed attend to the problem of political obligation: Margaret MacDonald's 'The Language of Political Theory'.12 MacDonald's immediate concern is the inadequacy of a crude positivistic approach to political philosophy that in certain circles was becoming the fashionable 'state of the art'.13 She points out that, contrary to the standard positivist position, political disagreement does not always seem to be based on disputed empirical issues or linguistic confusion, and remaining political disagreements can have enormous impact on human lives. Hence the positivist criterion of significance is not adequate to political philosophy. By way of case study, she turns her attention to the problem of political obligation, arguing that none of the leading accounts - social contract, tradition, utilitarian - provide a general answer, and that instead each holds part of the truth. According to MacDonald there is an indefinite set of vaguely shifting criteria, differing for different times and circumstances. Consequently:

The value of the political theorists, however, is not in the general information they give about the basis of political obligation but in their skill in emphasizing at a critical moment a criterion which is tending to be overlooked or denied. ${ }^{14}$

I find this an exceptionally useful insight. Note, though, that the political theorists may not conceive of themselves as engaged in this task. They are more likely to believe that they have come to understand the single, previously 
overlooked, truth about a topic and that their view - perhaps even their ideal theory or blueprint for society - should replace all previous false accounts. It may be that at the highest level political philosophy can only succeed if it has an overwhelming ambition and false self-conception. Yet its role in practice, at best, will be to modify existing practice rather than replace one set of practices with an entirely different alternative. In relatively recent decades, for example, to remain within the topic of political obligation, the rise of philosophical anarchism, especially through the work of Robert Paul Wolff ${ }^{15}$ and A. John Simmons, ${ }^{16}$ has led not to the abandonment of government, but the assertion of individual autonomy in the face of growing centralization of power. In response, proponents of the 'principle of fairness', such as George Klosko, ${ }^{17}$ remind us of the benefits of stable government.

We can illustrate MacDonald's claims further by means of a debate that occurred in relation to the drafting of the Universal Declaration of Human Rights, immediately after the Second World War. During the drafting process some of the contributors became uncomfortable that the document seemed very onesided: all the obligations seemed to be piled on the state and all the rights on the individual. The Soviet Union is said to have found the absence of a 'declaration of human duties' especially troubling. ${ }^{18}$ In a sense, one could say, the criticism is that the Universal Declaration failed to include an account of political obligation. In answer to this objection Charles Malik, from the Lebanon (a philosopher who studied under both Whitehead at Harvard and Heidegger at Freiburg), argued:

The problem of human rights arose in recent years precisely because society and the state trespassed upon man, to the extent, in totalitarian states, of choking him altogether. In our formulation we are therefore called upon to correct the excesses precisely of statism and socialism. The right amount of anarchism and individualism is exactly what statism and socialism need. It is not that we find ourselves at present in a lawless jungle with every man brutally seeking his own individual advantage without any organized lines of relation and authority; and as a result we are called upon, so to speak, to restore order and authority by reminding men of their duties and obligations: It is rather that we find ourselves 
today in a situation, all the world over, in which man's simple, essential humanity-his power to laugh and love and think and change his mind, in freedom-is in mortal danger of extinction by reason of endless pressures from every side. ${ }^{19}$

Malik's point, then, was not that individuals do not have duties to the state, but that now - 1948 - is not the time to emphasize this thought. Rather, some states have shown astonishing disregard for the rights and freedoms of individuals, including those of their own citizens, and it is necessary to grasp the opportunity to rebalance the relation in favour of the individual. Implicitly, he suggests, there may be other times when it is important to assert the duties of the individual to the state.

To retrace our steps, I do not think it is being suggested today that political philosophy is dead. We are not worried by logical positivism. Sociology does not have the undermining power it was once thought to have. True, wars are still being fought, but not on the scale of the Second World War. What, then, is our concern? Primarily, I think, it is a version of what Rawls calls the 'burdens of judgement'. ${ }^{20}$ By this I understand the idea that in relation to political ideas the 'free use of reason' will lead different people in different directions and to different conclusions, and there is no standard of proof to which they can be held. This is not to endorse the positivist view that strictly speaking any such statements are meaningless. It is not a semantic thesis. Neither is it to suggest that there are no standards of rigour. Some arguments are fallacious, or very poorly supported by evidence. Nevertheless, processes of reasoning will rarely leave us with just one conclusion. Our problem, therefore, is that there are too many apparently sound answers to many questions in political philosophy. Philosophical reasoning may settle issues in the head of those propounding particular arguments, but reasoning on its own generally lacks the power to shift others who have deeply held political views, whether or not backed by arguments of their own. This, of course, is the observation made by MacIntrye referred to above.

Sometimes this point is put in terms of irreconcilable value conflict. But that seems to me not exactly to express our problem. It is rarely accurate to say 
that political disagreement is a consequence of people holding different values. By and large, I think, we all hold pretty much the same values. Who is against liberty? Or, suitably understood, equality? Or relief of extreme need? Where we differ, typically, is how to weigh them when they come into conflict. ${ }^{21}$

Yet we are not paralysed. At any time a set of political institutions and practices is in place, informed, by design or accident, by a set of values or other factors. There is, we might say, a set of status quo policies and a set of status quo values, which, in stable times, support those policies. At other times, however, there will objections to the policies and a social critic will either attempt to demonstrate that the policies are out of kilter with society's values, or argue that we need to shift our values in such a way that they will no longer support the policies. In some cases the criticism will be very radical, calling for what may seem to be a total redirection of policy and approach. On MacDonald's analysis, however, a social commentator - who may or may not have a professional status as a political philosopher - is likely to have misunderstood his or her own contribution to the debate. A trenchant critique will be possible because, socially, it can be argued that what now may seem to be undue, or too little, weight is given to one factor, perhaps as a result of an earlier attempt to make a correction. This, I think, is where Margaret MacDonald's observation is so helpful. It could be, for example, that while 1948 was the time to emphasize the rights of individuals against the state, it is not impossible that by some later period the situation will need to be rebalanced; a debate that is regularly revived, especially in the light of perceived terrorist threat.

Certainly I do not want to argue that all political philosophy falls into the pattern that MacDonald has offered, or that this is the only way in which political philosophy can influence policy. But I do think MacDonald has identified something very important, although we need to realize that what she says really point to major movements in political philosophy rather than the day to day contributions of most political philosophers. The type of change in emphasis of values that MacDonald points to is something akin to a Kuhnian 'paradigm shift', when a new way of looking at a problem takes hold, rather than normal science, where the details of a new view, and problems with it, are sifted over with a fine toothcomb, ${ }^{22}$ although unlike Kuhn in this case it is better to regard the contrast 
as representing two ends of a continuum rather than a stark distinction. Within the problem of political obligation, for example, we can see the rise of the theory of the social contract, with Hobbes, Locke and Rousseau, its decline with Bentham and Mill, and its revival in modified form with Rawls, as examples of ways in which values were emphasized, minimized and then re-affirmed. Few political philosophers can make a contribution of such significance, but many will contribute to the refinement and advocacy of values.

\section{Political Philosophy and the Welfare State}

How, though, do these methodological reflections bear on our present topic, the welfare state? It is worth, once more, returning to British political theory of the 1950s, at a time when the welfare state in the UK, in its post-war Beveridge fullyfledged form, was not yet even a decade old: to Anthony Crosland, former Oxford Economics don, who had in 1955 lost his seat as a Labour MP, and thus had the leisure to finish writing his 1956 book The Future of Socialism. ${ }^{23}$

Reading the early chapters of The Future of Socialism one is struck by the confidence - perhaps even the heartbreaking complacency - with which Crosland reports upon a political consensus. National real incomes are rising. ${ }^{24}$ Full employment has been achieved, ${ }^{25}$ and partly as a result, the capitalist class has lost its power, for the workers have no fear of long-term unemployment. ${ }^{26}$ Laissez-faire is dead and buried. ${ }^{27}$ The mixed economy in which, according to Crosland, $25 \%$ of workers are employed by the state and in which over $50 \%$ of investment is made, is regarded as here to stay. ${ }^{28}$ No conservative government, it was suggested, would be able to undo more than a small portion of post-war reforms. ${ }^{29}$ 'The national shift to the Left, with all its implications for the balance of power, may be accepted as permanent.'30 The NHS - a mere eight years old - is already regarded as a fixture; severe poverty apparently eradicated; full employment achieved; and income inequality within reasonable bounds. Keynes did indeed, it seems, have all the answers.

Still, not all is right with Crosland's Britain; with disapproval and regret he notes that it has a rigid class structure, which even rising incomes for the lower classes has not eroded. Class is no longer correlated with income: highly 
skilled workers may earn more than many of their middle class neighbours, but nevertheless they are divided by habits, accents, manners, and worst of all, attitudes to each other. ${ }^{31}$ Socialism still has work to do: 'We have plenty of less fortunate citizens still requiring aid; and we certainly have not got an equal or classless society, nor one characterized by “co-operative' social relations."'32

Yet at the same time counter-currents were swelling. In the United States Milton Friedman's Capitalism and Freedom, published in 1962, but based on lectures first given in 1956, the year of The Future of Socialism, would restate the case for laissez-faire that Crosland had declared extinct. ${ }^{33}$ No doubt Crosland would have regarded such ideas as eccentric or irrelevant in the UK at the time, perhaps even anachronistic, writing:

Capitalism was historically associated with an explicit, assertive, and in the perspective of history, unusual ideology. Its essential features were, first, the veneration of individualism and competition: secondly, an insistence on the absolute and unconditional rights of private property: thirdly, an intellectual belief that the unfettered exercise of private rights must, by 'the invisible hand' of economic competition, maximize the welfare of the community.

None of these beliefs could be said to form part of the ruling ideology in Britain today. The non-capitalist classes have always opposed an ideal of co-operation, social action, and collective responsibility to that of individualism; and as their power grew, so this idea increasingly prevailed. No one would argue that in the contemporary Welfare State the dominant ideology was one of self-help or aggressive individualism. And even within the business class itself, as Chapter 1 has shown, the worship of individualism has given way to a positive cult of team-work and group action. $^{34}$

Crosland's world is one in which particular values are paramount: perhaps best described as fairness tempered by compassion and solidarity. Fairness means that traditional privilege is to replaced by opportunities for all. Compassion 
requires concern for the needs and interests of all; especially those who would suffer in a ruthless laissez-faire economy. Solidarity generates a sense, not only of 'team-work and group action', but that the poor should not be made to grovel. Assistance should not be regarded as a matter of Christian charity. All have rights, and should be granted the necessary entitlements and protections to have access to the means of well-being without having to rely on the arbitrary goodwill of others. Indeed such a view may well underlie Rawls's A Theory of Justice, ${ }^{35}$ which is why Stuart Hampshire in his 1972 review, was able to praise it in the following terms:

[A] noble, coherent, highly abstract picture of the fair society, as social democrats see it. In England, books about the Labour Party's aims ... needed just such a theory of justice as this, stated in its full philosophical generality. This is certainly the model of social justice that has governed the advocacy of R. H. Tawney and Richard Titmuss and that holds the Labour Party together. Society must repair the cruelties of nature, and it exists not only to preserve law and order but also to correct the natural differentials between the strong and the weak, and to give institutional support to self-respect, which is for Rawls a primary value. ${ }^{36}$

Contrast Crosland, and Hampshire's account of Rawls, however, with concern for the poor as it appears in Friedman:

[The classical liberal] will regard private charity directed at helping the less fortunate as an example of the proper use of freedom. And he may approve state action designed at ameliorating poverty as a more effective way in which the great bulk of the community can achieve a common objective. He will do so with regret, however, for having to substitute compulsory for voluntary action. ${ }^{37}$

Like it or not, Friedman's position fits beautifully into Margaret MacDonald's account of the value of political theories: 'emphasising at a crucial moment a 
criteria which is tending to be overlooked or denied'. On reading Friedman, and, ten years later, Robert Nozick, ${ }^{38}$ and then later still, Friedman's re-stating of his position in his co-authored volume (with his wife Rose Friedman) Free to Choose ${ }^{39}$ one is struck that a key value appears to be missing from the picture provided by Crosland: individual responsibility, or as Crosland puts it 'self-help'. Indeed the importance for Friedman of the notion of responsibility is brought out in the first paragraph of Capitalism And Freedom, in criticism of J.F. Kennedy's famous remark 'Ask not what your country can do for you. Ask what you can do for your country.' In response, neither possibility, says Friedman, represents an attractive vision. The first ignores the free man's 'belief in his own responsibility for his own destiny'. ${ }^{40}$ And the second assumes a view of government in which it has ends of its own and threatens to become a 'Frankenstein'. ${ }^{41}$

Friedman and Nozick point out that the anti-laissez-faire world, providing entitlements to the means to well-being for the marginalized, underplays the fact that those means only exist as a result of other people's efforts. ${ }^{42}$ All would be acceptable, on Friedman's view at least, if the only people who received benefits were genuinely unable to help themselves. However, once the system exists, it places power in the hands of people who may use it, unfairly, to their own advantage, according to the critics on the welfare state. By contrast, the value of responsibility suggests that those who have chosen a pattern of life that leaves them without the means to well-being - the welfare scroungers or undeserving poor - have no rightful claim. Self-help is our right and duty, and Friedman quotes Dicey regretting the decline in 'faith in self-help'. ${ }^{43}$ Alongside this complaint is another: that some of the gainfully employed have become too powerful, especially through the collective bargaining of the trade unions, and are demanding and receiving more than their contribution warrants. Crosland himself points to the power of the trade unions; 'even under the Conservative Government the Trade Unions remain effective masters of the industrial scene'. ${ }^{44}$ (For Friedman this situation is not acceptable, ${ }^{45}$ though of course it would be no better for him if the government controlled industry.

On its own, the advocacy of self-help may seem at best rather quaint or dated as an idea. Indeed, suggesting that those in a difficult situation should, in 
the first instance, look to their own resources can appear mean-spirited or narrow-minded. But when added to a growing sense of urgent economic crisis no or low growth, runaway inflation, declining tax revenues, rising unemployment, falling balance of payments, and so on - economies need to be made, and those who defend generous or undifferentiated welfare benefits may be wrong-footed. We retain a duty to help those who genuinely are unable to look after themselves, almost all will agree. But, according to the value of responsibility, when times are hard we need to take a careful look to ensure that we are not also helping those who, in fact, are perfectly capable of taking care of themselves. And, to revert to a theme from Crosland, when unemployment rises, economic power shifts from the worker to employers, who are then in a better position to influence the future direction of society. Indeed the rise of the Friedmanite view may be evidence that Crosland's claimed consensus was a thin veneer achieved by the political classes, while underneath ordinary belief and discourse had never fully abandoned ideas of 'self-help' and individual responsibility.

When it is perceived that society faces economic pressures, a tension between solidarity and responsibility becomes acute. Compassion, most agree, requires helping those who cannot look after themselves. Responsibility requires, or at least permits, not assisting those who can take care of themselves. But solidarity, so it appears, requires institutions that make it very hard to distinguish between those who can, and those who cannot, help themselves. ${ }^{46}$ The rise of responsibility has been accompanied by the fading away of solidarity: those who claim welfare benefits are seen not so much as fellow citizens who also have rights to a common pot, but as a mixture of the helpless and of possible fraudsters, who need to be checked carefully to ensure that they are not cheating or gaming the system.

One consequence of such attitudes to claimants, accompanied often by low rates of welfare benefits, it that the prophecy has, to a degree, become selffulfilling. Within the system of welfare benefits in the UK, there is, I would argue a hidden manifest injustice. It may not be on the scale of Sen's missing women, or famine victims, or have the shock value of marital rape, but nevertheless it affects perhaps hundreds of thousands of people in the UK. In the attempt to 
ensure that only those in genuine need receive help, two measures have been adopted. One is to ensure that welfare benefits are as low as feasibly they can be, so as not to give those capable of work an incentive to avoid it. The other is to have rigorous programmes of enforcement against those who attempt, illegally, to supplement their welfare benefits through working. As a result we have brought into existence a large group of people commonly referred to as 'benefit cheats'.

Now I have no doubt that there are some people engaged in fraud in a systematic and clearly criminal fashion. But I am more interested in people who are unable to find a job with decent pay and conditions, and so, reluctantly, claim state benefits. Yet these benefits are sufficient only for a basic level of existence. If you have a family, can you afford to buy birthday presents? Can you afford a night out now and again? Can you afford the fare to visit friends and family? A report for the Joseph Rowntree Foundation found that, according to their survey, one of the greatest necessities of life was 'being able to visit friends and family in hospital' (behind 'beds and bedding for everyone', 'heating to warm living areas of the home' and 'damp-free home', but above 'medicines prescribed by a doctor' and 'two meals a day'). ${ }^{47}$ This - alongside the other things mentioned - can be very difficult for people on benefits given the cost of even public transport.

Simply in order to provide themselves with the necessities of life many people on benefits engage in minor acts of criminality. Some work a few hours a week for cash, often in domestic cleaning. Some purchase goods they strongly suspect to be stolen. Some drive without tax or insurance. These are 'victimless crimes' at least at the first remove. And they are undertaken not out of a 'criminal mentality' or greed, but simply to be able afford the things that other people take for granted. But the fact that people are acting outside the law makes these people vulnerable to arrest, prosecution, public humiliation, fines or even a prison sentence. And, of course, this is a group that cannot complain about their situation without thereby admitting to criminal actions that could see them jailed, and thus the group is silenced. The situation of such people is troubling in itself, but also likely to lead to chronic stress, which in turn is very likely to lead to health problems. On my account these people suffer from severe disadvantage, which I understand as being in a situation of significant 
disadvantage where the available strategies for improving your situation put you at significant risk of making yourself much worse off (in this case, a court appearance, prison or fines, and public disgrace). ${ }^{48}$

I would contend that this is a situation of manifest injustice. True it is not as striking as Sen's examples of famines or missing women, but then examples of injustice in the developed world are likely to be less striking than those on a global scale. Nevertheless I think it is hard for anyone to consider the case just made and conclude it is perfectly reasonable that those who cannot find a job must live at an intolerable level of poverty if they wish to remain within the confines of the law. I can imagine someone trying to argue that I have the proportions wrong, and most benefit cheats are not as I have described. Or someone arguing that any attempt to reform the situation will make things worse in some way. But I find it hard to think of people who could accept the description and think there is not even reason to consider reform of the welfare stat. A reform that, perhaps paradoxically, out of solidarity would make some form of self-help more available to claimants.

My suggestion, then, is that the values upon which the welfare state was founded included compassion and solidarity (no doubt there were other values, and indeed considerations of efficiency, as can be found as the basis for Beveridge's arguments for a tax funded health system ${ }^{49}$ ). Arguably this combination of values paid insufficient attention to the idea of individual responsibility in both its positive form - goods come into the world through the efforts of individuals - and its negative form - those who are capable of looking after themselves but fail to do so have no claim on others. Once raised and defended with vigour, these considerations concerning responsibility, which were always present in some form, became prominent once again in public ideas and debates, and then, when combined with a sense of economic crisis were able to come to the fore, via the theories of Friedman and to a lesser extent Nozick, and exemplified in the deliberate rolling back of the welfare state in the policies of Thatcher and Reagan.

On both the philosophical and public front, the notion of responsibility has not received the level of challenge it might have done. As is well documented contemporary egalitarian thought has attempted to recapture the notion of 
responsibility within an egalitarian picture; ${ }^{50}$ and in the UK thirteen years of Labour government did little to throttle back on the notion of responsibility. As a result the position of the least advantaged, those very people that the system is designed to help, have increasingly been under attack, with declining benefits, and greater scrutiny in terms of whether they genuinely meet the full conditions for support.

How, then, could the tide be turned? It would not, I think, be attractive or politically wise to try to deny that people should be responsible for their own fate where they can be. Rather, the programme to follow would be to emphasise once again the values of fairness, compassion and solidarity, and, as I have suggested elsewhere, let a doctrine of responsibility find its way in the space left by the more aggressive assertion of other values, rather than being treated as our pre-eminent value. ${ }^{51}$

\section{Conclusion}

My purpose, in this essay, has been fourfold. One is to understand one role that the political philosopher can play in contribution to policy debates. I have argued that however political philosophers conceive of their task, in effect the major contribution of the most significant figures in the discipline is, as Margaret MacDonald put it, to remind us of a consideration - an important value - that has been relatively neglected (or conversely given too much weight) in current arrangements. Second I have tried to illustrate MacDonald's thesis by exploring the development of thinking about the welfare state, especially in the UK, by considering how the 1950's consensus under-emphasised the value of responsibility (or self-help) which then received powerful defence by Friedman and Nozick. Such notions came to be more dominant than solidarity, which is now 'relatively neglected'. Thirdly, I have argued that the emphasis on responsibility has done considerable damage to a large group of people who are now forced to break the law on a regular basis in order to live a minimally decent life. And so, finally, I suggest - no more than that - that now is the time to reemphasise the value of solidarity, and reduce the concern for individual responsibility. Somewhat paradoxically however, this may be best achieved by a 
political philosopher who ignores the analysis of this paper, and has the selfconfidence to out forward an ideal blueprint of society in which the idea of solidarity is the sole governing valaue. 52

${ }^{1}$ Bernard Williams, In The Beginning Was The Deed (Princeton: Princeton University Press, 2003), p. 23-4.

${ }^{2}$ I have argued elsewhere that, for example, an imperfect attempt to implement luck egalitarianism can take us not half way to equality, but to libertarianism. See Jonathan Wolff, 'Fairness, Respect and the Egalitarian Ethos', Philosophy and Public Affairs 27, 2 (1998): 97-122.

${ }^{3}$ Amartya Sen, The Idea of Justice (Cambridge Ma.: Harvard University Press, 2009).

${ }^{4}$ Frederick Engels, Socialism Utopian and Scientific, in Robert C. Tucker (ed.) The Marx-Engels Reader (second edition) (New York: Norton, 1978) p. 693-4.

${ }^{5}$ Alasdair MacIntyre After Virtue (London: Duckworth 1981) p. 8.

${ }^{6}$ Amartya Sen, Poverty and Famines (Oxford: Oxford University Press, 1981).

${ }^{7}$ Amartya Sen, 'More than 100 Million Women are Missing', New York Review of Books, 37, December 20 th 1990. Note that the demographics were distorted well before the widespread adoption of ultrasound, which has made selective abortion an option.

${ }^{8}$ For further discussion of how to understand this position, see my 'Social Equality and Social Inequality', in Social Equality: Essays on What It Means to Be Equals, ed Carina Fourie, Fabian Schuppert and Ivo Wallimann-Helmer (Oxford: Oxford University Press, 2014).

${ }^{9}$ Peter Laslett (ed.) Philosophy, Politics and Society (Oxford: Basil Blackell).

${ }^{10}$ Laslett op. cit., p. vii.

${ }^{11}$ Laslett op. cit., p. vii.

12 Margaret MacDonald, 'The Language of Political Theory', Proceedings of the Aristotelian Society 41 (1940-410); 91-112.

${ }^{13}$ For discussion of the influence of logical positivism on the development of political philosophy see Jonathan Wolff 'Analytic Political Philosophy' in Michael Beaney ed. The Oxford Handbook of the History of Analytic Philosophy (Oxford: Oxford University Press, 2013), pp. 795-822.

14 MacDonald op. cit. p. 112. 
15 Robert Paul Wolff, In Defence of Anarchism (New York: Harper and Row, 1970).

${ }^{16}$ A. John Simmons, Moral Principles and Political Obligations (Princeton N.J.:

Princeton University Press, 1981).

17 George Klosko, The Principle of Fairness and Political Obligation (Lanham MD:

Rowman and Littlefield, 1992).

18 Mary Ann Glendon, A World Made New: Eleanor Roosevelt and the Universal

Declaration of Human Rights, (New York: Random House, 2001) p. 165.

19 Charles Malik, "Talk on Human Rights," 1949, cited in Jonathan Wolff, The

Human Right to Health (New York: Norton) pp. 147-8.

20 John Rawls, Political Liberalism 2nd Revised Edition (New York Columbia

University Press, 2004), pp. 54-58.

${ }^{21}$ For some empirical support for this conjecture, see Jonathan Haidt, The

Righteous Mind (London: Allen Lane, 2012).

22 Thomas Kuhn, The Structure of Scientific Revolution (Chicago: University of

Chicago Press, $4^{\text {th }}$ Edition 2012).

${ }^{23}$ Anthony Crosland, The Future of Socialism (London: Constable, 2008 [1956]).

${ }^{24}$ Crosland, op. cit., p. 5.

25 Crosland, op. cit., p. 6.

26 Crosland, op. cit., p. 9.

27 Crosland, op. cit., pp. 33-8.

${ }^{28}$ Crosland, op. cit., p. 9.

${ }^{29}$ Crosland, op. cit., p. 31.

30 Crosland, op. cit., p. 11.

${ }^{31}$ Crosland, op. cit., pp. 119-142.

32 Crosland, op. cit., p. 79.

33 Milton Friedman, Capitalism and Freedom (Chicago: University of Chicago

Press, 1962).

${ }^{34}$ Crosland, op. cit., p. 35.

35 John Rawls, $A$ Theory of Justice (Oxford: Oxford University Press, 1971).

${ }^{36}$ Stuart Hampshire, 'A New Philosophy of the Just Society', New York Review of

Books, 24 Feb. 1972, p. 3.

${ }^{37}$ Friedman, op. cit., p. 195

38 Robert Nozick, Anarchy, State, and Utopia (New York: Basic Books, 1974).

39 Milton Friedman and Rose Friedman, Free to Choose (London: Penguin, 1980).

${ }^{40}$ Friedman, op cit, p. 1.

41 Friedman, op cit. p. 2.

42 In Anarchy, State, and Utopia Nozick of course thought of himself as putting forward a uniquely correct picture, in contrast with the earlier views of others. Later, in The Examined Life, he saw things in terms strikingly reminiscent of MacDonald:

Let us suppose that there are multiple competing values that can be fostered, encouraged, and realized in the political realm: liberty, equality for previously unequal groups, communal solidarity, individuality, self-reliance, compassion, cultural flowering, national power, aiding extremely disadvantaged groups, righting past wrongs. Charting bold new goals (space exploration, conquering disease), mitigating economic inequalities, the fullest education for all, eliminating discrimination and racism, protecting the powerless, privacy and 
autonomy for its citizens, aid to foreign countries, etc. .... Not all of these worthy goals can be pursued with full energy and means, and perhaps these goals are theoretically unreconcilable also, in that not all good things can be adjusted together into a harmonious package. (p. 292)

The electorate I see as being in the following situation: Goals and programs have been pursued for some time by the party in power, and the electorate comes to think that's far enough, perhaps even too far. It's now time to right the balance, to include other goals that have been, recently at least, neglected or given too lower a priority, and it's time to cut back on some of the newly instituted programs, to reform or curtail them (p. 294)

Robert Nozick, The Examined Life New York: Simon and Schuster 1989.

43 Friedman, op. cit., p. 201.

${ }^{44}$ Crosland, op. cit., p. 65.

45 Friedman and Friedman, op. cit., pp. 270-286.

46 I have argued for this in more detail in my 'Fairness, Respect and the Egalitarian Ethos'.

47 David Gordon et al., Poverty and Social Exclusion in Britain (York: Joseph Rowntree Foundation, 2000), p. 15.

${ }^{48}$ For brief elaboration, see Jonathan Wolff and Avner de-Shalit, 'On Fertile Functionings: A Response to Martha Nussbaum', Journal of Human Development and Capabilities 14, 4 (2013): 161-165.

49 William Beveridge, Social Insurance and Allied Services (London: HMSO, 1942).

50 For discussion see my 'Equality: The Recent History of an Idea', Journal of Moral Philosophy 4, 1 (2007): 125-136.

51 See my 'Training, Perfectionism and Fairness', Journal of Applied Philosophy 21, 3 (2004): 285-295.

52 This paper is based on a talk originally prepared for a conference on Ideal Principles and Real Politics in London in 2012. I thank Ingrid Robeyns for her reply to the paper on that occasion as well as the audience for a very helpful discussion. It also draws on a presentation at the Priority in Practice conference in Frankfurt in 2012. I would like to thank Christian Schemmel, Stefan Gosepath, Chris Brooke and an anonymous referee for their excellent suggestions on how I might develop the paper, as well as an audience in Newcastle in 2014 for very valuable discussion. 